\title{
Analysis and comment
}

\section{Health policy \\ An independent NHS?}

In April this year, Fiona Godlee wrote in her editor's choice that the UK health service needs to be protected from party politics to halt the rapid turnaround in policies that seem to be destabilising the system. She argued that an independent NHS authority could be run by a board of governors responsible for managing health care within a set budget and a broad political framework. We asked four opinion leaders for their views on whether it is time to give the NHS more independence.

\section{Democratic control is essential}

Stephen Thornton

If healthcare had been deemed too important to leave to the politicians, as advocated by Fiona Godlee, ${ }^{1}$ we would never have had a National Health Service. Its birth was a deeply controversial political act. Just because we happen to be living through a period of political consensus which believes that healthcare should be tax funded, free at the point of use, and available for all regardless of the ability to pay, it doesn't mean it was ever thus or will be in the future. A recent visit to the United States brought powerfully home to me what happens in a society where healthcare is not viewed as a right for all citizens. While millions go without insurance cover and liberal pressure groups wring their hands, there's little political will for radical reform.

Discussion and debate about the future of the NHS requires democratic political means. As others have said much more eloquently than I, the most difficult choices in any society are not those between good and evil but between two goods. In any system where staffing or financial resources are limited and where demand is potentially unlimited, tough choices have to be made. Markets or networks? Competition or collaboration? Comprehensiveness or safety net? Patient focused or doctor driven? With or without complementary therapies? All these are contentious issues; we all have a position to take on them, and each affects our health and wellbeing and that of our families and our communities. Democratic checks and balances are the best way to ensure we continue to move the NHS in the right direction, not the creation of a barely accountable technocracy that would place all power in the hands of professionals and bureaucrats.

\section{Effective control}

Our starting point, therefore, should not be to remove the NHS from politics but to build more robust

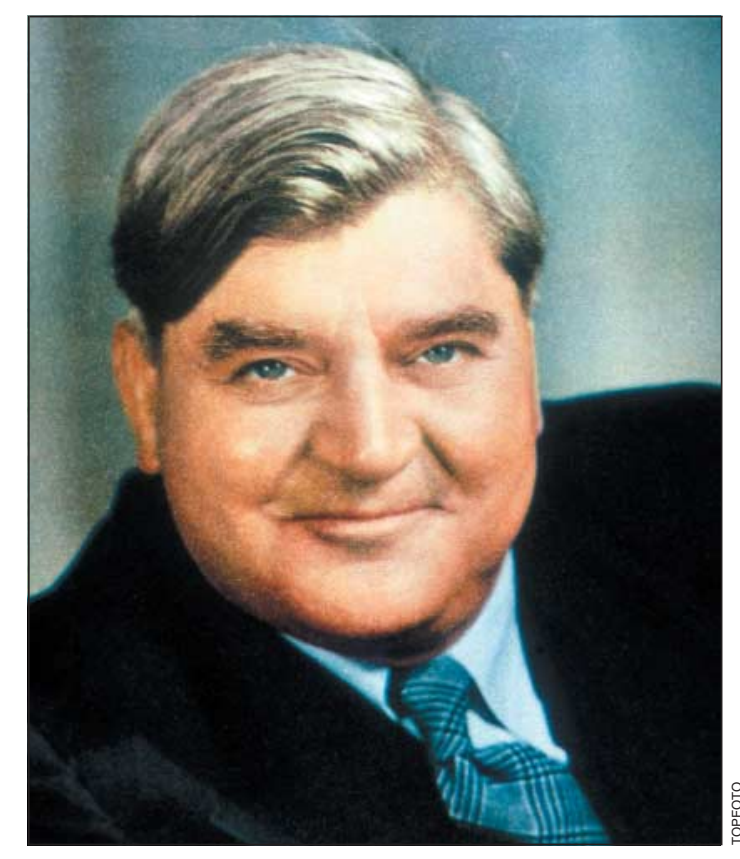

Nye Bevan: without him the NHS might not exist

democratic institutions around it. The key issue is how to do this more effectively than at present. The trick is to deal with the democratic deficit in policy making and commissioning while giving much more operational freedom to healthcare providers.

Firstly, more powerful mechanisms of parliamentary scrutiny of ministerial policy should be considered. English parliamentary democracy tends to hand undue power to the executive, and this needs to be challenged.

Since its inception, power broking in the NHS has always been a balancing act between central policy making and local delivery. Despite the many well
The Health Foundation, London WC2E 9RA Stephen Thornton chief executive stephen.thornton@ health.org.uk BMJ 2006;333:251-2 
publicised policy initiatives to the contrary, ${ }^{23}$ that balance has shifted too far to the centre in recent years. So, secondly, all options to strengthen local democratic control of the big choices in health care should be on the table for consideration: regional government for strategic decision making at strategic health authority level; the democratisation of primary care trusts; and perhaps, most contentiously, the integration of NHS commissioning into local government.

As with all democratic institutions, none of these changes would ensure perfection, but they would be better than handing power to an unaccountable quango.

\section{A third way}

Gwyn Bevan

Department of Operational Research, London School of Economic and Political Science, London WC2A 2AE Gwyn Bevan professor of management science

R.G.Bevan@lse.ac.uk
The question of NHS independence is being raised because of the belief that it has been damaged by a series of reorganisations and dramatic shifts in policies. The Department of Health has been reorganised three times; the regional structure and purchasing tier in the NHS have each been reorganised four times; there have been mergers of providers of acute services and reorganisation of mental health services; and inspectorates have been created, expanded, abolished, and merged (with one lasting 17 days). ${ }^{1-5}$ The policy of a market driven by provider competition in which money followed the patient was introduced in 1991, abolished in 1997, ${ }^{1}$ and reintroduced from $2006,{ }^{3}$ after a five year interregnum during which the NHS was subjected to annual star ratings, a Soviet-style regime of targets backed by sanctions and rewards. ${ }^{78}$

The sequelae of tumultuous continuing change during the years of unprecedented increases in resources ${ }^{4}$ include large financial deficits, ${ }^{9}$ low productivity, ${ }^{10}$ and deep cynicism in clinicians, who see each innovation as having a half life of two to three years before it is either abolished or displaced by another.

\section{Competition or targets}

The question of independence of the NHS is essentially a question of governance that, since the destruction in 1996 of an effective regional tier, ${ }^{11}$ has in effect been a choice between a competitive market or a target regime. Tuohy ${ }^{12}$ argued that a competitive market, as introduced in 1991, contradicted the logic of the NHS, which is determined by two key structural elements: clinical decision making by doctors through collegial relationships (in general practice and hospital), which meant that doctors determined demand and supply rather than "purchasers" and "providers," and ministerial accountability, which resulted in ministers interfering so that hospitals would not be allowed to fail in the market.

The system of star ratings was designed to remedy the ineffectiveness of the threat of competition and to be consistent with the logic of the NHS. It did not seek to override collegial decision making by doctors, and where it identified organisations as failing, it did not seek to destabilise them financially but put the jobs of their chief executives at risk. ${ }^{8}$ Star ratings resulted in
Contributors and sources: ST has more than 20 years of management experience in the NHS, having worked at hospital, community health, health authority, regional, and national levels of the service. This article reflects his experiences as a former NHS manager and his current role as chief executive of the independent healthcare charity, the Health Foundation.

Competing interests: None declared.

Godlee F Time to leave home [Editor's Choice]. BMJ 2006:332. (1 April) 2 Department of Health. Patients first: consultative paper on the structure and management of the National Health Service in England and Wales. London: DoH, 1979

3 Department of Health. Shifting the balance of power within the NHS: securing delivery. London: $\mathrm{DoH}, 2001$.

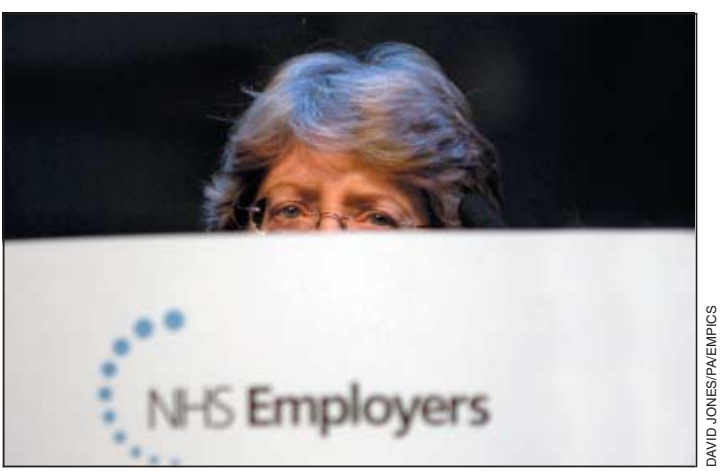

Patricia Hewitt: dealing with a disgruntled workforce

large reductions in waiting times as required by the most important targets, but there were two problems: various kinds of gaming ${ }^{13}$ and the centre imposing the same targets and rules for assessing performance regardless of history and local circumstances. What was needed was to develop a system that was more sensitive to local variations, but that would have required an effective regional tier. ${ }^{14}$

In the absence of an effective hierarchy, the only alternative to a system of centrally driven targets was another try at provider competition. Perhaps when that is also found wanting, there will be a return to a similar target regime. So my call for independence for the NHS is designing systems of local accountability that would offer an effective alternative to the idea of provider competition.

Competing interests: GB was director of the office for information on health care performance at the Commission for Health Improvement (CHI), which was central to the expansion of $\mathrm{CHI}$ 's powers and responsibilities as announced in January 2002. The abolition of CHI was announced in April 2002.

1 Secretary of State for Health. The new NHS. London: Stationery Office, 1997. www.dh.gov.uk (search for: 0101380720).

2 Department of Health. Shifting the balance of power. London: DoH, 2002 www.dh.gov.uk (search for: 26434).

3 Secretary of State for Health. Learning from Bristol: the Department of Health's response to the report of the public inquiry into children's heart surger at the Bristol Royal Infirmary 1984-1995. London: Stationery Office, 2002. www.dh.gov.uk (search for: $\mathrm{Cm}$ 5363).

4 Secretary of State for Health. Delivering the NHS plan. London: Stationery Office, 2002. www.dh.gov.uk (search for Cm 5503).

5 Department of Health. Commissioning a patient led NHS. London: DoH 2005. www.dh.gov.uk/assetRoot/04/11/67/17/04116717.pdf (accessed 20 June 2006) 
6 Secretaries of State for Health, Wales, Northern Ireland and Scotland. Working for patients. London: HMSO, 1989.

Secring of Sate for Healh. The NHS Pin London: Stationery Office, Secretary of State for Health. The NHS Plan.
2000. www.dh.gov.uk (search for: 010481829 ).

2000. wh dh.gov.uk (search for.010481829). Bevan G, Hood C. What's measured is what matters: targets and gaming in the English public health care system. Public Admin (in press).

9 Ham C. Turning around NHS deficits. BMJ 2006;332:131-2.

10 UK Centre for the Measurement of Government Activity. Public service productivity: health. Econ Trends 2006;628:26-57.
11 Ham C. The politics of NHS reform 1988-97. London: King's Fund, 2000:2.

12 Tuohy C. Accidental logics. The dynamics of change in the health care arena in the United States, Britain and Canada. New York: Oxford University Press, 1999.

13 Bevan G, Hood C. Have targets improved performance in the English NHS? BMJ 2006;332:419-22.

14 Bevan G. Setting targets for health care performance: lessons from a case study of the English NHS. Natl Inst Econ Rev (in press).

\title{
NHS authority may not fix what isn't really broken
}

\author{
Stephen Gillam
}

In the face of another funding crisis, the government has resorted to the usual diversionary tactic of tinkering with structures. The sense of a government flip-flopping about has increased calls once more for a relationship that puts the NHS at arm's length from ministers, whom everyone blames for meddling and short termism.

The case for an independent NHS authority has been made several times in the recent past. ${ }^{12}$ This body, the argument goes, could put politicians and parliamentarians in their proper place: developing policies. Public debate over the role and remit of such a body would increase transparency in the policymaking process. No longer preoccupied with daily fire fighting, health ministers might start to tackle the effects of poverty, the environment, food, housing, and education on health. Politicians would remain at the heart of strategic decisions while allowing the NHS authority's non-elected executives to take responsibility for implementing policy. Parliament would provide the forum for agreeing the agency's objectives and hold it accountable for delivering them. This would increase faith in the process of standard setting for the NHS thereby, or so it is asserted, increasing ownership by the rank and file of national targets. $^{2}$

\section{Problem of style not substance}

But isn't the fundamental problem here as much one of governmental style, ultimately self defeating, born of disdain for bureaucratic models of policy making and parliamentary process? Would an authority working to these masters necessarily have defied the laws of unintended policy consequences or got the contractual sums right? This centralist and controlling administration always seemed likely to crush the NHS under the weight of its good intentions. "Shifting the balance of power" soon became devolution by devilishly detailed directive. The hands of primary care trust executives were tied by voluminous, sometimes conflicting, guidance. However, ministers can resist the impulse to meddle, and civil servants in the Department of Health don't have to be marginalised by policy nerds working out of the prime minister's office.

Certainly, an enormous gulf exists between policy makers and the frontline, but primary care trusts could have been given greater discretion to establish their own objectives or depart legitimately from central policy. Objectives could be determined with more open debate (though staff will never own targets that seem to reduce the complexity of their everyday

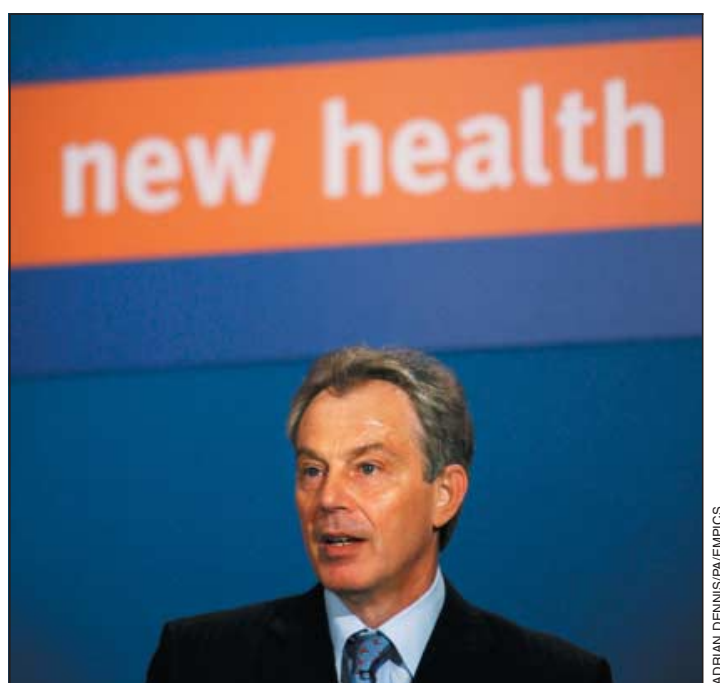

Lea Vale Medical Group, Liverpool Road Health Centre, Luton LU1 1HH Stephen Gillam general practitioner sjg67@medschl. cam.ac.uk

BMJ 2006;333:253-4

encounters to bean counting). With a more refined system of scrutiny than the current select committee system, parliament could continue to provide accountability.

\section{Effects of independence}

The notion that public sector accountability runs in a direct and hierarchical fashion from individual health provider to the secretary of state for health presents difficulties. But there are advantages too, such as Tony Blair's famously impromptu commitment to raise funding levels to the average for countries in the Organisation for Economic Cooperation and Development. To what extent should we separate responsibility for developing policy from responsibility for implementing it? Is it not more likely that this separation would reduce the public's commitment to an increasing plurality of service providers under the banner of NHS plc. And wait till the Daily Mail gets its teeth into the running costs of a new, presumably regionalised, quango.

A particular deceit lies in suggesting that the establishment of an NHS authority does not imply any particular approach to health policy. The prime role of this body would be to manage an expanding new market, channelling public funds to commercial providers. It would give cover to something the government in control of the NHS would never otherwise get away with. The NHS will become a glorified commissioning agency as what used to be a national service becomes 
an amalgam of free floating foundation hospitals, NHS trusts, private companies, and traditional primary care providers. Where is the evidence to suggest that surreptitiously increasing private provision will benefit patients in my inner city practice? We may now, indeed, be ruled by fundamentalists whose faith in markets, competition, and the profit motive as the sole path to effective public service is unshakeable. ${ }^{3}$ Paradoxically, an NHS agency could spearhead the crusade.

\title{
Steadying the NHS
}

\author{
Donald M Berwick, Sheila Leatherman
}

Institute for Improvement, 20 University Road, Cambridge, MA 02138 USA Donald M Berwick president

\section{School of Public} Health, University of North Carolina, USA Sheila Leatherman research professor

Correspondence to: D M Berwick dberwick@ihi.org

BMJ 2006;333:254-5
We believe, and refuse to be dissuaded, that the National Health Service, with its moral intent, commitment to equity, and store of knowledge, has the inherent capability to become the greatest healthcare system of any nation. Yet, lately, it seems like a boxer on the ropes, not the champion it should be.

\section{Laudable goals}

Fiona Godlee has raised a critical question about governance at the right time. ${ }^{1}$ The vision of modernisation of the NHS that emerged in the first year of the labour government was, and remains, compelling. ${ }^{2}$ Tony Blair personally led the articulation of an ambitious set of goals for reinvestment in and improvement of care, and he put his money-lots of money-where his mouth was.

The national service frameworks that early on defined targets for better care in areas including cancer, coronary heart disease, and mental health were scientifically grounded and patient focused. Infrastructure for catalysing change grew rapidly, including the concept of clinical governance embedded in law, new regulatory organisations, new forms of accountability for NHS management and the medical professions, and growing transparency through publicly reported data. Before this, no nation had undertaken such ambitious large scale improvement in health care. ${ }^{3}$

Dr Godlee may give too little credit for the successes over the past few years-better access, reduced mortality, more reliable care for heart disease, better coordination of cancer care, and improved ratings by patients, to name a few. ${ }^{4}$ But the growing distress and the failure to capitalise fully on the vast new investments are evident, and the current financial crisis in the NHS renders even the best reforms increasingly vulnerable.

\section{Shifting strategies}

Surely some of this gap is due to unceasing shifts of structures and strategies since the NHS Plan was published in 2000. In barely six years, four people have been secretary of state, and several of the government's most senior healthcare advisors-none clinicians-have come and gone. Fundamental institutions such as the strategic health authorities and primary care trusts have been through two reorganisations. Foundation trusts have been promulgated, with major changes in
Contributors and sources: SG has undertaken extensive policy research, particularly in the field of primary care. He has worked closely, but not too closely, with politicians and policy makers. Competing interests: None declared.

\footnotetext{
Dewar S. Government and the NHS-time for a new relationship. London: King's Fund, 2003.

Langlands A. Synchronising higher education and the NHS. London: Nuffield Trust, 2003.

3 Tudor Hart J. The white paper: contest for contracts. Br J Gen Pract 2006;56:303.
}

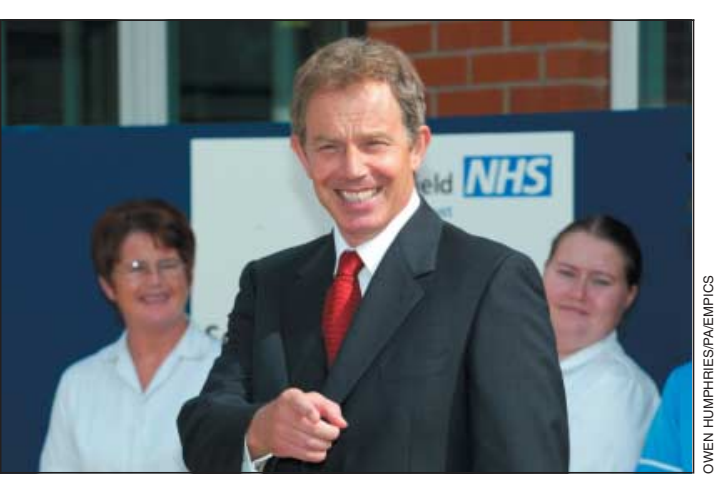

Tony Blair put his money where his mouth was

hospital incentives. ${ }^{5}$ The world's largest investment in healthcare information technology is underway, implemented through complex contracts with multiple vendors. ${ }^{6}$ New contracts are in place for general practitioners and specialists, with unexpected soaring payments to clinicians who, at the same time, are dropping night time and weekend surgeries.

Policy has focused on market forces and choice. Private companies with values far different from those of the NHS are being invited into delivery and commissioning. As Americans, we know dependence on market forces for constructive change is playing with fire.

Each of these steps makes sense to someone. However, collectively, they do not cohere. The panoply of changes, the sudden policy corrections, and the impatience that makes plans end before gaining traction create confusion and cynicism for even a willing workforce. If the NHS was a publicly traded company, stockholders would flee because of its unsteadiness of course. Dr Godlee attributes this inconsistency to the whims of politics and politicians. We do not know the cause; we have too much respect for the many thoughtful leaders we have come to know in the NHS and the government to attribute the inconsistency to either lack of caring or lack of competence. We applaud Labour's original plan for "modernisation." But like Dr Godlee, we wonder whether something big should change to steady the NHS on its worthy, inspiring journey.

Perhaps it is time for a national review of the NHS governance and managerial structure, rather than another restructuring of the organisation within the NHS. Our bias would be not to remove NHS 
leadership too far from government power; it might prove unwise to trade the constructive role of engagement for independence. Politicisation is one side of a coin with involvement on its obverse. The key question, however, is: "How should an NHS fit for the 21st century be governed and managed as a whole?" And, most importantly, "How can the proper set of nonnegotiable social and ethical commitments the NHS began with-equity, access for all, free at the point of care, and public funding, etc-be preserved and enhanced within a structure more consistent in its directions and plans?"

The NHS is not just a national treasure; it is a global treasure. As unabashed fans, we urge a dialogue on possible forms of stabilisation to better provide the NHS with the time, space, and constancy of purpose to realise its enormous promise.

Contributors and sources: DMB and SL have met and consulted with NHS and Department of Health leaders often in the past decade, and have both studied and reported on progress and issues in the NHS modernisation process. They have worked separately on projects focused on evaluating and improving the NHS, sponsored by the Nuffield Trust and The Health Foundation.

Competing interests: None declared.

1 Godlee F. Time to leave home [Editor's Choice]. BMJ 2006;332. (1 April.)

2 Department of Health. The new NHS. London: Stationery Office, 1997. www.archive.official-documents.co.uk/document/doh/newnhs/ contents.htm (accessed 28 June 2006).

3 Leatherman S, Sutherland K. The quest for quality in the NHS: A mid-term evaluation of the ten-year quality agenda. London: Nuffield Trust, 2003.

Leatherman S, Sutherland K. The quest for quality in the NHS: A chartbook on quality of care in the UK. Abingdon: Radcliffe Medical Press, 2005.

5 Department of Health. A short guide to NHS foundation trusts. London: Department of Health, 2005. www.dh.gov.uk (search for: 5591).

6 Department of Health. The national programme for IT in the NHS. London: Stationery Office, 2006. www.nao.org.uk/publications/nao_reports/0506/05061173es.pdf (accessed 28 Jun 2006).

7 Nichols LM, Ginsburg PB, Berenson RA, Christianson J, Hurley RE. Are market forces strong enough to deliver efficient health care systems? Confidence is waning. Health Aff (Milwood) 2004;23(2):8-21.

(Accepted 10 July 2006)

\title{
Confidentiality and consent in medical research Consent for the use of personal medical data in research
}

\author{
Peter Singleton, Michael Wadsworth
}

Properly obtained consent is needed for all clinical trials, yet one size doesn't necessarily fit all. This article looks at different consent models and emphasises the need to support choice rather than just observing the formalities of "gaining consent"

This article deals mainly with the secondary use of medical records in research; primary use may have been for a clinical trial or for medical treatment. Well known examples of successful secondary use of data are discovery of the links between antidepressants and suicide and between tranquilisers and road accidents. ${ }^{12}$ These insights are important, even if they are not conclusive and may need to be confirmed by specific studies or trials.

Explicit consent is needed for all aspects of clinical trials, including the retention of medical records, either as identifiable data or in anonymised form. ${ }^{3}$ Consent is usually for that trial only (this can go to extremes; see box 1). Difficulties can arise over re-use of data, either for new questions that arise within the study, or for questions that could be considered once the data have been gathered but were not anticipated at the outset when consent was gained. In terms of efficiency and consistency of results, it is preferable to re-use data rather than re-collect it. Projects should therefore allow participants to choose at the outset whether data (and possibly tissues) can be retained for future research in a secure and confidential form.

The two main legal instruments are the Data Protection Act 1998 (DPA98) and the common law of confidence (confidentiality), which are discussed in another article in this series. ${ }^{4}$ Essentially, consent is needed to use personal data in medical research unless the person is dead; the researchers are all healthcare professionals or equivalent; or the data do not identify the person.

\section{Box 1: How much consent is enough?}

Recently, one of us was a subject in a research study in which a blood test was assessed. He had to sign four forms. One form covered consent to participate in the study, and 10 questions were asked; a second form was designed to waive any intellectual property rights; the two other forms were for a related study by the same team on diet-the forms were the same, but the study title was different. It took longer to complete the forms than for the blood samples to be taken, although not as long as it took to complete the nutritional questionnaire that followed.

The research ethics committee was worried that on reflection participants might change their mind about the study, so participants were given a fifth form to take away, complete, and send back to the study coordinator. If this form was not signed and returned, then the person could not be included in the studies.

This procedure did not recognise personal autonomy-the right to be able to agree with the proposal without the unnecessary administrative burden on the participants and research team. The extra paperwork needed cannot be justified in terms of benefit to the participants.

Some people think that the common law of confidentiality is more restrictive than the Data Protection Act as data are given in confidence to clinicians, so consent is always needed. In this article, we will assume
This article is the second in a four part series, building on a recent Medical Research

Council initiative relating to the use of personal information in medical research

Centre for Health Informatics and Multi-professional Education

(CHIME),

University College London, London N19 5LW

Peter Singleton principal research fellow

continued over

BMJ 2006;333:255-8 